\title{
Burning season effects on the short-term post-fire vegetation dynamics of a Mediterranean heathland
}

\author{
Blanca Céspedes, Belén Luna, Beatriz Pérez, Itziar R. Urbieta \& José M. Moreno
}

\author{
Keywords \\ Fire management; Fire regime; Fire \\ seasonality; Land-use change; Prescribed fire \\ Nomenclature \\ Tutin et al. (1964-1980) \\ Abbreviations \\ ES early season; LS late season; NMDS \\ non-metric multidimensional scaling \\ Received 11 July 2012 \\ Accepted 22 May 2013 \\ Co-ordinating Editor: Tim O'Connor
}

Moreno, J.M. (corresponding author, josem.moreno@uclm.es), Céspedes, B. (blanca.cespedes@uclm.es), Luna, B. (belen.luna@uclm.es), Pérez, B. (beatriz.perez@uclm.es), \& Urbieta, I.R. (itziar.rodriguez@uclm.es) : Department of Environmental Sciences, University of CastillaLa Mancha, Toledo, 45071, Spain

\begin{abstract}
Question: What are the short-term (first 4 yrs) dynamics of a Mediterranean heathland following burning during the early- vs the late-fire season?

Location: Serra da Lousã, Central Portugal.

Methods: The vegetation studied was a 16-year old heathland with Erica australis (resprouter), Pterospartum tridentatum (resprouter/seeder) and Erica umbellata (seeder) among the dominant species. Four blocks, each with three $50 \mathrm{~m} \times$ $40 \mathrm{~m}$ plots, were established. One plot per block was burned during the early season (ES) and one during the late season (LS), and the third remained unburned. Prior to, and during the first 4 yrs after burning, each burned plot was sampled for species abundance, vigour and richness. The effects of fire through time were tested using random blocks repeated measures ANOVA. Recruitment was modelled as a function of percentage of post-fire soil covered by litter (\%). MANOVA was used to test changes in the relative dominance of the woody species due to fire. Community dynamics were assessed by NMDS ordination analysis.
\end{abstract}

Results: Fire severity was higher and the percentage of post-fire soil covered by litter lower in ES than LS burns. The post-fire plant dynamics were dominated by the resprouting response. Resprouting was not affected by burning season, but ES fires resulted in higher seedling recruitment than LS fires, particularly in the dominant seeder E. umbellata. Seedling recruitment was negatively related to post-fire soil covered by litter. Additionally, seedling emergence was delayed by nearly 1 yr in LS fires with respect to ES fires. Species richness was higher in ES than LS fires. Fire did not globally affect the relative abundance of the dominant species, although the seeder $E$. umbellata decreased its relative cover with respect to the other dominant species. Ordination analysis showed that the postfire dynamics of the vegetation were on a track of convergence with the community existing before fire.

Conclusion: Burning season differentially affected regeneration, mainly by its effect on seeding, with little effect on resprouting. Burning season and associated changes in fire severity and soil covered by litter could alter the short-term regeneration dynamics, which can have important implications for managing this highly flammable vegetation.

\section{Introduction}

In seasonal climates, fires at different times during the year could affect the post-fire regenerating vegetation through a number of mechanisms. Plant and soil moisture content vary over the year, as does vegetation flammability and fire intensity (Hodgkinson 1991). Furthermore, soil water content modifies heat penetration into the soil, due to wet soils being poor heat conductors (Frandsen \& Ryan 1986).
Hence, changes in fire intensity (sensu Keeley 2009) and in heat penetration could affect responses such as plant and seed mortality, time of resprouting and the number of active resprouting buds per plant (Malanson $\delta$ Trabaud 1988; Cruz et al. 2003; Vesk \& Westoby 2004).

Fire seasonality may affect plant responses related to phenological processes. First, the sensitivity of plant tissue to fire, notably of seeds, can change depending on level of hydration (Parker 1987), which varies with the season. 
Additionally, many plants undergo seasonal changes in their chemical constituents in various organs, including total carbohydrate content (Cruz \& Moreno 2001), which could affect resprouting (Jones \& Laude 1960). Similarly, the size and composition of the soil seed bank (Traba et al. 2006; Céspedes et al. 2012) changes over the year. Moreover, the breaking of dormancy may also be affected by burning season (Ooi 2010). Once a fire occurs, the period until conditions are appropriate for either resprouting or seed germination will vary depending on the season of burning, which could also affect the post-fire vegetation.

Despite the number of factors that could directly or indirectly affect vegetation responses to fire in relation to burning season, experimental evidence in Mediterranean environments is not conclusive. While some studies have found that burning season affects resprouting (Papanastasis 1980; Malanson \& Trabaud 1988), whereby autumn fires were more detrimental to plant regeneration than spring fires, other studies did not (Konstantinidis et al. 2005, 2006). Effects of fire season on post-fire regeneration via resprouting remain poorly understood (Lamont et al. 2011). Furthermore, similar studies in Mediterranean ecosystems on post-fire regeneration from the soil seed bank often failed to find significant effects (Moreno et al. 2011).

Nowadays, most fires are caused by human intervention, particularly in Mediterranean areas (San-MiguelAyanz \& Camia 2009), thus expanding the fire season. Furthermore, prescribed burning, a tool used to manage fire-prone areas, is normally conducted out-of-season (Pollet \& Omi 2002; Knapp et al. 2009; Montiel \& Kraus 2010). Understanding the response of vegetation to changes in the season of burning therefore remains an important issue in Mediterranean fire-prone ecosystems.

This study investigated the effects of season of burning on regeneration of a Mediterranean heathland by comparing experimental burns conducted during the early (May) and late (October) fire season. After fire, plant regeneration was monitored for 4 yrs. The system was chosen because it contained a mix of woody species with different regeneration strategies, including species that resprout from a lignotuber, which have received little attention. The question of whether woody species with different regeneration strategies (resprouting vs seeding) differ in their response was addressed. Consequently, do changes in the season of burning affect species richness or the relative dominance of the species? Mediterranean heathlands cover extensive areas of the humid siliceous lands of the western Iberian Peninsula and northern Morocco (Loidi et al. 2010). Their high flammability (Ojeda et al. 2010) offers a large window during the year in which to conduct prescribed burning. Answering these questions could be relevant for managing heathlands to temporarily reduce landscape hazards associated with burning (Fernandes $\delta$ Botelho 2003).

\section{Methods}

Study site

The site was located at Gestosa, 850 m a.s.l., Serra da Lousã (Central Portugal) $\left(40^{\circ} 15^{\prime} \mathrm{N}, 8^{\circ} 10^{\prime} \mathrm{W}\right.$; Appendix S1). The stand chosen was a 16-yr-old shrubland that developed after a wildfire had burned a Pinus pinaster woodland. This consisted of a heathland dominated by species with firepersistence mechanisms, either by resprouting $\left(\mathrm{R}^{+} \mathrm{S}^{-}\right)$, seeding $\left(\mathrm{R}^{-} \mathrm{S}^{+}\right)$or both $\left(\mathrm{R}^{+} \mathrm{S}^{+}\right)$. Specifically, the heathland was dominated by Erica australis L., an obligate resprouter $\left(\mathrm{R}^{+} \mathrm{S}^{-}\right.$) from a well-developed lignotuber (Moreno et al. 1999), and the obligate seeder $\left(\mathrm{R}^{-} \mathrm{S}^{+}\right)$Erica umbellata Loefl. ex. L., being the very scarce herbaceous stratum (Appendix $\mathrm{S} 2)$. The climate is mediterranean-humid, with $11^{\circ} \mathrm{C}$ mean annual temperature and $933 \mathrm{~mm}$ mean annual rainfall (see Appendix S1). The bedrock is granitic and the soils are stony, deep and fine textured (distric cambisols; FAO 1974).

\section{Experimental design}

Four blocks, each with three $50 \mathrm{~m}$ x $40 \mathrm{~m}$ plots, were selected on a northeast-facing slope. The fire season in Portugal is from June to September (76\% of fires) (Catry et al. 2009). Plots within a block were randomly assigned to burning early (ES, 19 May) or late (LS, 29 October) in the fire season, or left unburned. Precipitation during the first year after fire was above average, but below average during the next 3 yrs; temperatures during the first 4 yrs after fire were slightly above normal, and no particular unusual frost episodes were recorded (Appendix S1). Fire severity was estimated based on differences between pre-fire and post-fire standing biomass and litter. Based on stem diameters or crown dimensions, separate allometric equations were constructed for each species to calculate pre-fire total above-ground biomass and its distribution among various size fractions (Appendix S3).

In the spring before burns, plant cover (\%) was visually estimated for herbaceous (annuals and perennials), woody (total, individual species) and fern (Pteridium aquilinum) species in ES and LS plots. For the dominant shrubs, density (no. individuals $\mathrm{m}^{-2}$ ) and height $(\mathrm{cm})$ were measured. These variables were recorded at $20 \mathrm{~lm} \times 1 \mathrm{~m}$ permanent quadrats regularly distributed along two $20 \mathrm{~m}$ transects within each plot. Species richness was derived based on presence/absence data of the $1 \mathrm{~m}^{2}$ quadrats.

After burning, similar measures were carried out simultaneously for the two treatments during each of the first 4 yrs after fire at $1 \mathrm{~m}^{2}$ permanent quadrats. These were 
conducted in late spring (second half of June), at the end of the growing season. Measurements included plant cover (\%; differentiating between resprouts and seedlings for the main shrubs) and species richness (herbaceous and woody species). Resprouting plants were counted within the permanent $1 \mathrm{~m}^{2}$ quadrats, whereas seedlings were counted in the $50 \mathrm{~cm} \times 50 \mathrm{~cm}$ permanent quadrats located within them. Plant vigour was assessed from measures of seedling height $(\mathrm{cm})$ and maximum length of resprouters $(\mathrm{cm})$. In addition, during the first post-fire sampling, soil covered by litter (\%) and bare ground were visually estimated within each $50 \mathrm{~cm}^{2}$ quadrat.

\section{Statistical analysis}

Plant abundance (cover, density), richness (all species, woody, herbaceous) and vigour (height, maximum resprout length) of individual woody species were tested for the effects of burning season [S] (two levels, early season [ES] and late season [LS]), time after fire [T] (four levels, each of the four post-fire years), and their interaction [S x T]. A randomized block ANOVA with repeated measures was applied. Prior to the analysis, data were tested for normality and homoscedasticity, and transformed as appropriate: arcsine (cover), square root (richness, density) and logarithmic (vigour). Furthermore, the relative abundance of each of the main woody species at the end of the monitoring period (fourth post-fire year) were compared with pre-fire values using repeated measures ANOVA including burning season [S] (ES and LS) as between-subject factor. As relative cover and density values are compositional data (they equal one) they were log-ratio transformed prior to analysis (Pawlowsky-Glahn \& Egozcue 2006). In addition, the changes induced by fire or season on the overall relative dominance (cover, density) of the main woody species from pre-fire to 4 yrs post-fire were tested by repeated measures MANOVA. All ANOVA analyses were implemented in SPSS v. 17.0 package for Windows (SPSS, Chicago, IL, US).

Differences in percentage soil covered by litter after fire were tested using random blocks ANOVA, with burning season as factor. Additionally, the relationships between percentage of post-fire soil covered by litter (\%) and seedling density were evaluated by fitting linear and non-linear models using maximum likelihood techniques and assuming a zero-inflated Poisson error distribution in the seedling data. The package likelihood v. 1.5 in R was used ( R Core Team, Foundation for Statistical Computing, Vienna, AT).

Finally, changes in the plant community composition from pre-fire to post-fire along the 4 yrs monitored were assessed using NMDS ordination (Clarke 1993) to species cover (\%) data. The Bray-Curtis Sørensen dissimilarity index was used with the PAST computer package (Hammer et al. 2001).

\section{Results}

Prior to burning, the stand was densely covered and dominated by four shrub and a few herb species (Table 1). No significant differences were found for either plant cover or density between ES and LS plots before fire $\left(\mathrm{F}_{1,3}=1.000\right.$, $P=0.609$ and $\left.F_{1,3}=1.007, P=0.389\right)$; block effects were also not significant $\left(\mathrm{F}_{1,3}=1.053, P=0.555\right.$ and $\mathrm{F}_{1,3}=$ 8.670 $P=0.069)$.

The ES fires were conducted at higher temperature and lower air humidity and litter moisture than the LS fires (Appendix S1), and consumed more biomass (3166 g. $\mathrm{m}^{-2}$ ) than the LS counterparts (1993 g.m ${ }^{-2}$; season $\mathrm{F}_{1,3}=7.626$, $P=0.033$; Appendix S3). Nonetheless, the interaction between burning season and sampling time (pre-fire vs post-fire biomass) was significant only for total biomass or for the fine fuel fraction, but not for the coarser fuel fraction or for the litter (see Appendix S3). On the other hand, the percentage soil covered by litter after fire was $5.7 \pm 2.0$ and $28.2 \pm 5.5$ in ES and LS, respectively; this difference being statistically significant $\left(\mathrm{F}_{1,3}=16.9, P=0.026\right)$.

A total of 18 species (eight herbs, one fern and nine woody shrubs) were recorded during the first 4 yrs after fire (Appendix S2). The post-fire dynamics were marked by the dominance in cover of woody species. Resprouting played a much larger role than seeding (Table 1). Burning season did not significantly affect cover of the resprouting woody species, neither of all of them as a group nor any of the main species (Tables 1 and 2). In contrast, burning season significantly affected cover of seedlings of all species as a group and of two species, Halimium alyssoides and particularly E. umbellata. Burning season also affected cover of herbaceous perennials. In all cases, cover was higher in ES than LS plots (Tables 1 and 2).

Burning season did not affect overall post-fire plant density (Table 2). Significant differences between ES and LS were only found for $H$. alyssoides on both regeneration mechanisms, with higher seedling density in ES than LS. In all three seeding species (E. umbellata, Pterospartum tridentatum and $H$. alyssoides), while ES fires produced new recruitment during the first and second post-fire year, LS fires generally did not produce recruitment until the second year.

Burning season did not significantly affect vigour of any species (Table 2). Nonetheless, a significant interaction between burning season and time after fire was found for E. australis, which, with time, tended to have higher vigour in LS plots despite lower first-year vigour. At the end of the fourth year, resprout vigour was generally several times higher than that of seedlings (Table 2). 
Table 1. Plant cover percentage (mean $\pm \mathrm{SE}$ ) of various groups of species before fire and during the first 4 yrs post-fires lit early and late in the fire season in an Erica australis heathland at Gestosa, Serra da Lousã (Central Portugal)

\begin{tabular}{|c|c|c|c|c|c|}
\hline \multirow[b]{2}{*}{$\begin{array}{l}\text { Species/ } \\
\text { Year }\end{array}$} & \multirow{2}{*}{$\begin{array}{l}\text { Early season } \\
\text { Mean } \pm \text { SE }\end{array}$} & \multirow{2}{*}{$\begin{array}{l}\text { Late season } \\
\text { Mean } \pm S E\end{array}$} & \multicolumn{3}{|c|}{ ANOVA $(P)$} \\
\hline & & & Season (S) & Time (T) & $S \times T$ \\
\hline \multicolumn{6}{|l|}{ All species } \\
\hline Pre-fire & $97.5 \pm 1.7$ & $97.5 \pm 1.7$ & & & \\
\hline Post-fire & & & 0.157 & $<0.001$ & 0.67 \\
\hline 1 & $39.2 \pm 5.2$ & $54.5 \pm 9.6$ & & & \\
\hline 2 & $49.3 \pm 3.8$ & $59.1 \pm 8.2$ & & & \\
\hline 3 & $57.8 \pm 4.1$ & $66.7 \pm 10.4$ & & & \\
\hline 4 & $69.8 \pm 3.6$ & $80.5 \pm 8.4$ & & & \\
\hline \multicolumn{6}{|c|}{ Woody species } \\
\hline Pre-fire & $97.5 \pm 1.7$ & $97.5 \pm 1.7$ & & & \\
\hline Post-fire & & & 0.083 & 0.007 & 0.444 \\
\hline 1 & $39.2 \pm 5.2$ & $54.5 \pm 9.6$ & & & \\
\hline 2 & $44.2 \pm 7.4$ & $52.9 \pm 10.4$ & & & \\
\hline 3 & $50.8 \pm 9.5$ & $59.8 \pm 13.0$ & & & \\
\hline 4 & $64.1 \pm 6.8$ & $76.7 \pm 11.0$ & & & \\
\hline \multicolumn{6}{|l|}{ Seedlings } \\
\hline Post-fire & & & 0.012 & 0.003 & 0.160 \\
\hline 1 & $3.1 \pm 0.6$ & $0.3 \pm 0.3$ & & & \\
\hline 2 & $3.7 \pm 0.8$ & $1.7 \pm 0.4$ & & & \\
\hline 3 & $6.0 \pm 1.8$ & $4.7 \pm 2.4$ & & & \\
\hline 4 & $13.1 \pm 3.6$ & $5.4 \pm 3.9$ & & & \\
\hline \multicolumn{6}{|l|}{ Resprouts } \\
\hline Post-fire & & & 0.053 & $<0.001$ & 0.463 \\
\hline 1 & $39.2 \pm 5.2$ & $54.5 \pm 9.6$ & & & \\
\hline 2 & $40.5 \pm 7.9$ & $51.1 \pm 10.8$ & & & \\
\hline 3 & $47.6 \pm 10.7$ & $60.2 \pm 14.1$ & & & \\
\hline 4 & $54.8 \pm 9.7$ & $72.4 \pm 13.2$ & & & \\
\hline \multicolumn{6}{|c|}{ Fern (P. aquilinum) } \\
\hline Pre-fire & $0.1 \pm 0.1$ & $0.5 \pm 0.4$ & & & \\
\hline Post-fire & & & 0.071 & 0.410 & 0.326 \\
\hline 1 & $1.0 \pm 1.1$ & $0.7 \pm 0.5$ & & & \\
\hline 2 & $1.3 \pm 1.4$ & $2.5 \pm 2.7$ & & & \\
\hline 3 & $0.9 \pm 1.0$ & $2.3 \pm 2.2$ & & & \\
\hline 4 & $0.7 \pm 0.8$ & $2.3 \pm 2.2$ & & & \\
\hline \multicolumn{6}{|c|}{ Herbaceous species } \\
\hline \multicolumn{6}{|c|}{ Annuals } \\
\hline \multicolumn{6}{|l|}{ Pre-fire } \\
\hline Post-fire & & & 0.851 & 0.003 & 0.027 \\
\hline 1 & & $0.1 \pm 0.1$ & & & \\
\hline 2 & $0.2 \pm 0.1$ & $0.4 \pm 0.2$ & & & \\
\hline 3 & $0.1 \pm 0.1$ & $0.1 \pm 0.1$ & & & \\
\hline 4 & $1.1 \pm 0.4$ & $0.3 \pm 0.3$ & & & \\
\hline \multicolumn{6}{|l|}{ Perennials } \\
\hline Pre-fire & $0.8 \pm 1.0$ & $0.2 \pm 0.1$ & & & \\
\hline Post-fire & & & $<0.001$ & $<0.001$ & 0.112 \\
\hline 1 & $6.0 \pm 3.6$ & $3.3 \pm 2.2$ & & & \\
\hline 2 & $9.2 \pm 5.3$ & $4.7 \pm 3.6$ & & & \\
\hline 3 & $11.3 \pm 6.6$ & $5.7 \pm 4.1$ & & & \\
\hline 4 & $10.6 \pm 4.7$ & $7.5 \pm 4.7$ & & & \\
\hline
\end{tabular}

Results of repeated measures ANOVA $(P)$ are shown for burning season (S, twice within the season, main treatment), time after fire ( $T$, first 4 yrs postfire, repeated measures) and their interactions $(S \times T)$. Statistically significant $P$-values $(\leq 0.05)$ are shown in bold.
The relationship between seedling density and percentage of post-fire soil covered by litter was negative in the three seeder species, for first- or for second-year recruits (Fig. 1). During the first year, recruitment was virtually restricted to ES plots with low post-fire litter. Recruitment increased from the first to the second year in all three species.

Species richness was very low before fire (either at $1 \mathrm{~m}^{2}$ or $20 \mathrm{~m}^{2}$ scale), there being few herb species (see Appendix S4). Species richness was significantly affected by burning season at the smaller scale but not at the larger one, being higher in ES than in LS. Although time after fire was a significant factor at both spatial scales, species richness changed little through time, with maximum values in the second year after fire (Appendix S4).

Neither fire nor burning season, or their interaction, were significant in affecting the overall relative dominance (cover, density) of the main woody species from pre-fire to four years post-fire ( $P>0.05$ in all cases; Appendix S5). Notwithstanding, the analysis for individual species showed that relative cover (E. umbellata) or density (H. alyssoides) significantly decreased in these species after fire (Fig. 2).

Fire was initially effective in modifying the community, as shown by NDMS ordination. However, over the 4 yrs, the dynamics of the community tended to converge toward the pre-fire situation (Fig. 3). No differences in these patterns were apparent for ES or LS plots.

\section{Discussion}

Burning a Mediterranean heathland early and late in the fire season did not produce major differences in the plant community 4 yrs after fire. The response dynamics of the post-fire plant community were rather rapid because of the dominance of resprouting by the woody species. Notwithstanding, not all species were equally affected: in woody species, while burning early or late in the fire season was almost never a significant factor for resprouters, it was significant for seeding species. Furthermore, the largest proportion of recruitment following late season fires was delayed until the second year after fire, whereas most recruitment following fires during the early season occurred during the first year after fire. Herbs were a minor component in this system, unlike other Mediterranean shrublands (Céspedes et al. 2012; Torres et al. 2012), but burning season did affect herbaceous perennials (Agrostis curtisii was the sole species).

Concerning resprouting of dominant shrubs, we expected that, at least during the first year, differences in resprouting cover or vigour between ES and LS burning would have emerged, because resprouting started 5 mo sooner following ES than LS burning. This pattern was vis- 


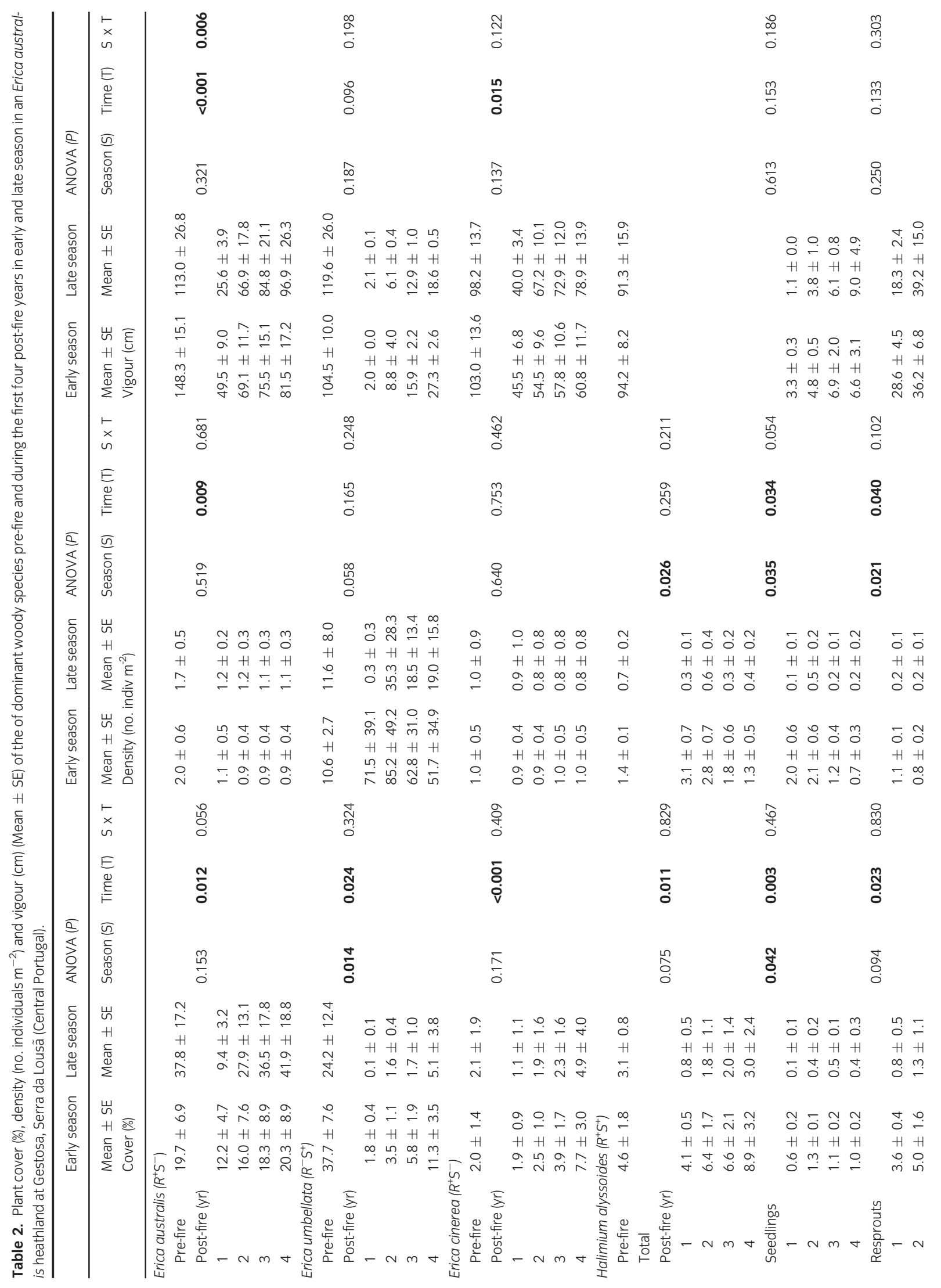




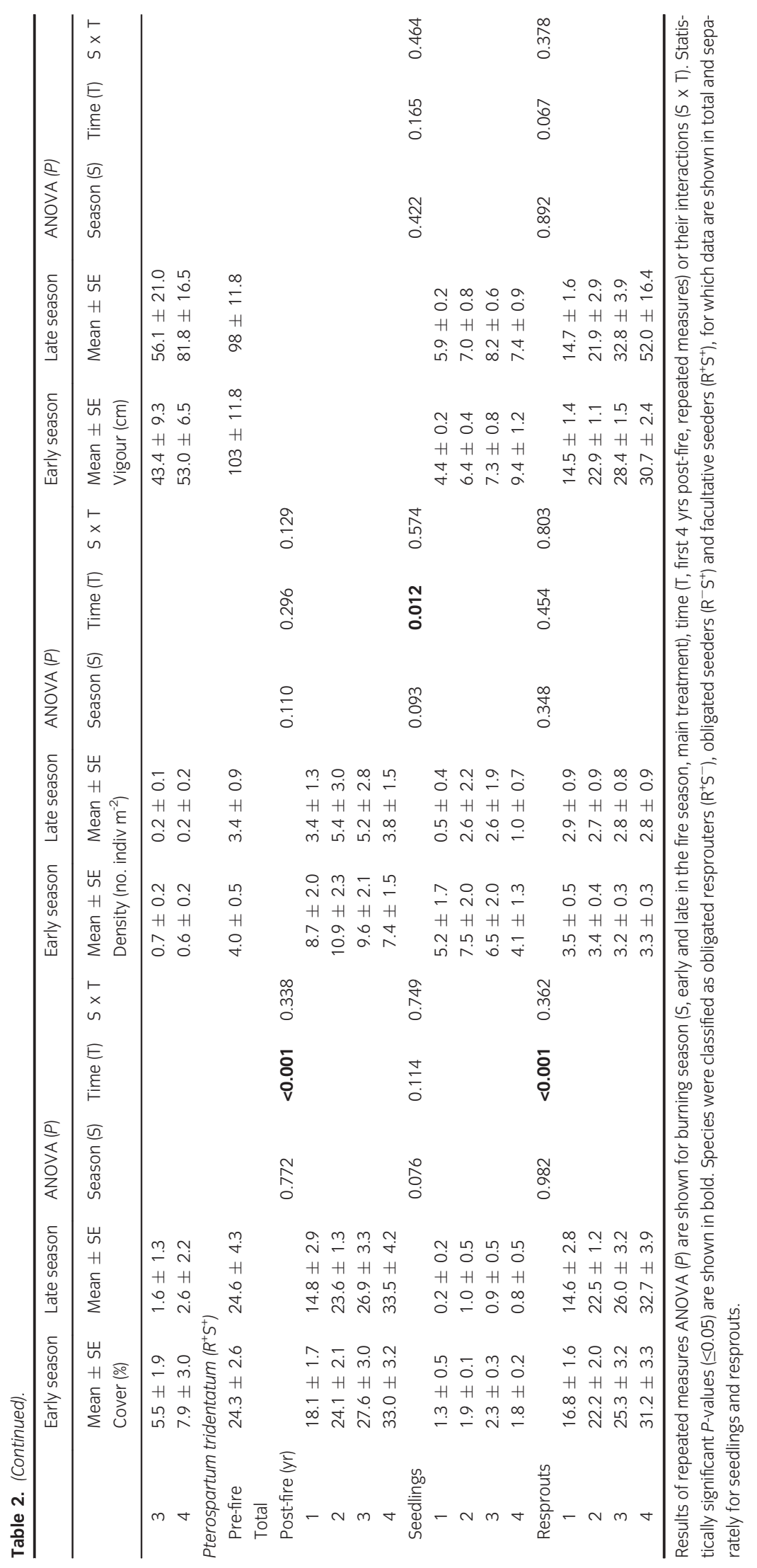



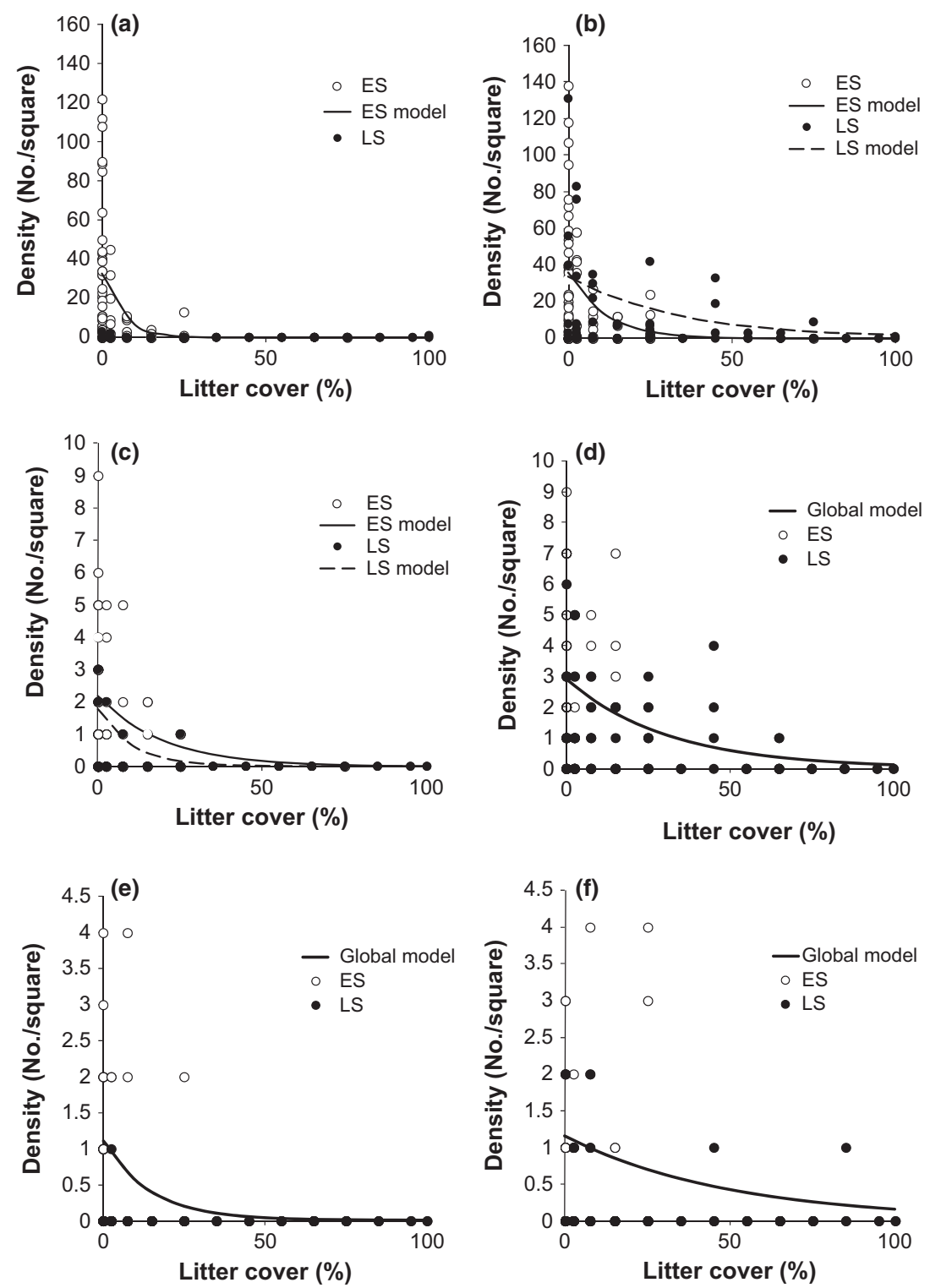

Fig. 1. Relationship between seedling density (no. $0.25 \mathrm{~m}^{-2}$ ) and percentage of post-fire soil covered by litter (\%) during the first (a, c, e, left panels) and second (b, d, f, right panels) post-fire years in early- (ES) and late- (LS) season fires in an Erica australis heathland at Gestosa, Serra da Lousã (Central Portugal). a, b Erica umbellata; c, d Pterospartum tridentatum; e, $\mathbf{f}$ Halimium alyssoides. Separate models for ES and LS fires are shown when significant $(P<0.05)$ based on log-likelihood ratio tests; otherwise, ES and LS data were pooled in one global model and shown when significant. $N=80$ (ES) and 70 $(\mathrm{LS})$.

ible for the dominant E. australis at the end of the first post-fire year, but these differences had disappeared by the following year. Although, in general, no significant effects of burning season were found for cover or vigour of resprouters, a significant interaction between burning season and time after fire was present for E. australis, showing that, over time, its LS resprouts became more vigorous. A similar pattern was visible for cover, i.e. with time, resprouting tended to be higher following LS than ES burning. Whether variations in fire severity or plant phenological changes contributed to this could not be determined. Burning in the early season resulted in generally higher seedling cover and density than burning in the late season, particularly for the obligate seeder E. umbellata. In relative terms, seeding was therefore favoured by early season burning. Nevertheless, dominance of this species was not restored to pre-fire levels during the first four post-fire years.

In general, our results document that ES burning was more favourable for recruitment from the soil seed bank 

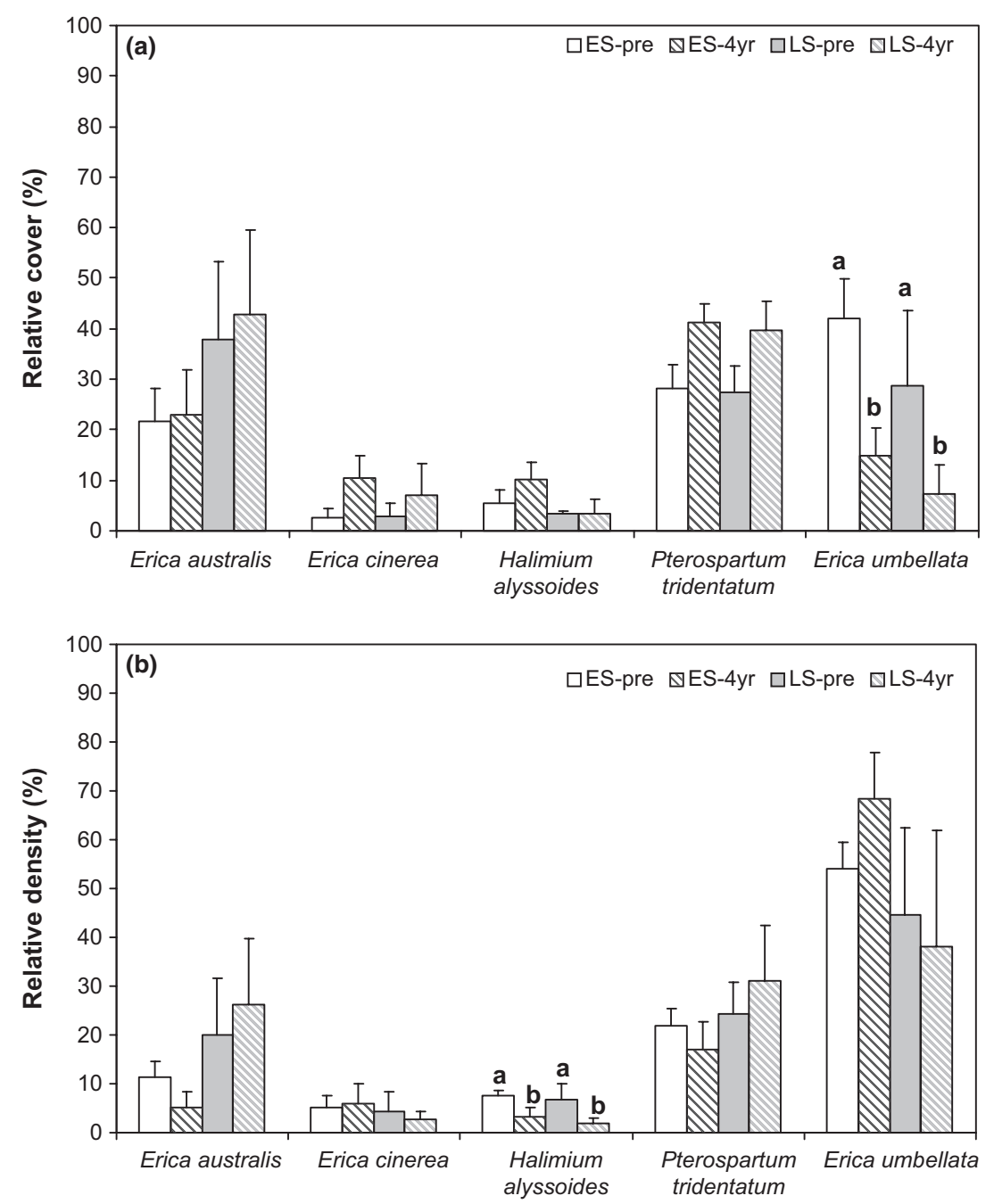

Fig. 2. Mean relative cover (a) and density (b) of the main woody species before and 4 yrs after fire in plots burned early and late in the fire season. Error bars indicate SE. Lower-case letters in bold denote comparison between pre- and fourth year post-fire differences based on ANOVA.

than LS burning, despite the fact that the three species analysed disperse their seeds in summer. The differences in total biomass consumed (more in ES than LS), i.e. fire severity, make it difficult to distinguish the relative importance of burning season vs fire severity in controlling this response. More so since differences in litter biomass consumed were not significant, yet the percentage of soil covered by litter after burning was higher in LS than ES. All three seeder species showed a negative relationship between percentage of post-fire soil covered by litter and recruitment (Fig. 1). This suggests that fire stimulatory effects on germination were highest in areas with higher fire severity and/or that conditions for germination were more favourable in these due to a lower percentage of soil covered by litter. Higher fire severity in ES fires would have induced higher germination in $H$. alyssoides and $P$. tridentatum, both of which have hard seeds whose ger- mination is promoted by heat (González-Rabanal \& Casal 1995; Valbuena \& Vera 2002; Núñez et al. 2003). The response of $E$. umbellata to fire cues is less well established (González-Rabanal \& Casal 1995; Moreira et al. 2010).

Most recruitment in LS fires was delayed until the second year. In contrast, most recruitment following earlyseason fires occurred during the first year. This is particularly relevant for an obligate seeder species such as E. umbellata, as this is its only regeneration mechanism (Reyes et al. 2009). Changes in rainfall patterns could further affect post-fire temporal emergence patterns in this and other seeder species. Moreno et al. (2011) showed that if the first year after fire is wet, most emergences occur during that year; but if this year is dry, then emergence can occur during the second and third years. In this study, rainfall during the first year after fire was far higher (1472 mm; 95th percentile) than the long-term average, 


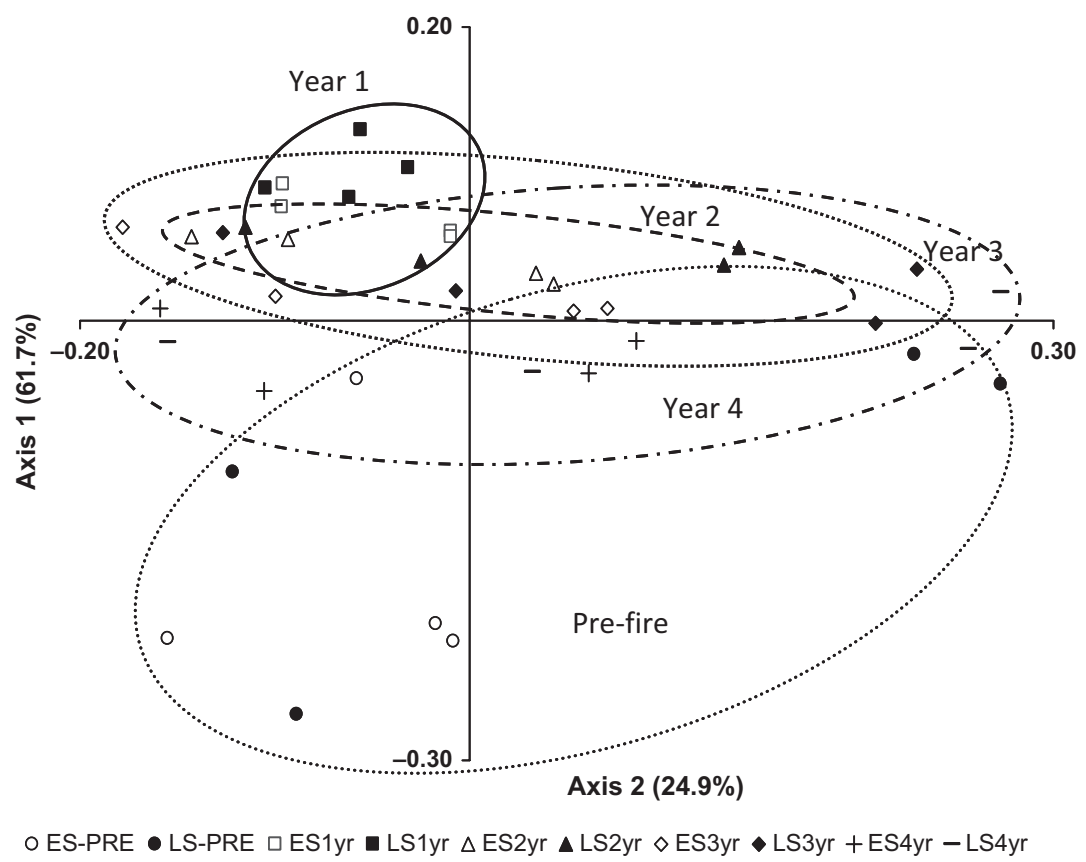

Fig. 3. NMDS ordination of plots based on plant cover (\%) of all species in pre-fire conditions and burned early (ES) or late (LS) in the fire season during the first 4 yrs (1-4 yr) after fire (stress: 0.083).

so it is unlikely that rainfall played a major role. Nonetheless, since recruitment took place during the first 2 yrs, notably in the second year for late season fires but also for early-season fires, it appears that other factors may be involved in controlling emergence and recruitment and that these are independent of the amount of soil covered by litter and of fire severity.

We demonstrated that a resprouter-dominated Mediterranean heathland could be highly resilient to fire (Ojeda et al. 1996; Calvo et al. 2002). Neither fire nor the time of year when this was conducted globally affected the relative dominance of the main species. This high resilience is similar to that reported for other resprouting-dominated shrublands (Papanastasis 1980; Malanson \& Trabaud 1988; Konstantinidis et al. 2005, 2006), but contrasts to some reports for seeder-dominated shrublands (Quintana et al. 2004; De Luis et al. 2006; Moreno et al. 2011). In this study, seeders (in particular the main species, E. umbellata) were most negatively affected by fire. E. umbellata has been shown to be at risk after fire in other experimental burns in Central Spain (Quintana et al. 2004; Moreno et al. 2011). Further studies are needed to establish the role of regeneration mode in the stability of shrublands to fire.

In considering the use of fire for managing the examined shrubland, it appears that fires conducted early in the season and of relatively high severity will be more appropriate to maintain the plant community. Late season, low severity fires can impair this heathland community. Because E. umbellata can play a major role in fire behavior due to its high flammability, changes in this species can further alter subsequent fire behaviour and, eventually, further contribute to modifying the heathland. Notwithstanding, resilience of this heathland is very high, and burning could reduce fire hazard over a limited number of years, independently of burning early or late in the fire season.

\section{Acknowledgements}

This research was supported by the EC (EVGl-CT200100027) and Caja de Guadalajara (grant CONV080174) to JMM. We thank the ADAI team for carrying the experimental fires and Helena Fernández, Juan Ángel Gracia and Ángel Velasco for help with the fieldwork. Writing benefited from the FUME project (ENV-2009-GA243888). Comments from Tim O'Connor, Jasper Slingsby and two anonymous reviewers helped improved the paper. The authors declare that they do not have any conflict of interest regarding this paper.

\section{References}

Calvo, L., Tárrega, R. \& De Luis, E. 2002. The dynamics of Mediterranean shrub species over 12 years following perturbations. Plant Ecology 160: 25-42. 
Catry, F.X., Rego, F.C., Bacao, F. \& Moreira, F. 2009. Modeling and mapping wildfire ignition risk in Portugal. International Journal of Wildland Fire 18: 921-931.

Céspedes, B., Torres, I., Luna, B., Pérez, B. \& Moreno, J.M. 2012. Soil seed bank, fire season, and temporal patterns of germination in a seeder-dominated Mediterranean shrubland. Plant Ecology 213: 383-393.

Clarke, K.R. 1993. Non-parametric multivariate analyses of changes in community structure. Australian Journal of Ecology 18: 117-143.

Cruz, A. \& Moreno, J.M. 2001. Seasonal course of total nonstructural carbohydrates in the lignotuberous Mediterranean-type shrub Erica australis. Oecologia 128: 343-350.

Cruz, A., Pérez, B. \& Moreno, J.M. 2003. Resprouting of the Mediterranean-type shrub Erica australis with modified lignotuber carbohydrate content. Journal of Ecology 91: 348356.

De Luis, M., Raventós, M.J. \& González-Hidalgo, J.C. 2006. Postfire vegetation succession in Mediterranean gorse shrublands. Acta Oecologica 30: 54-61.

FAO 1974. UNESCO Soil Map of the World 7, Legend. UNESCO, Paris, FR

Fernandes, P.M. \& Botelho, H.S. 2003. A review of prescribed burning effectiveness in fire hazard reduction. International Journal of Wildland Fire 12: 117-128.

Frandsen, W.H. \& Ryan, K.C. 1986. Soil moisture reduces belowground heat flux and soil temperatures under a burning fuel pile. Canadian Journal of Forest Research 16: 244-248.

González-Rabanal, F. \& Casal, M. 1995. Effect of High-Temperatures and Ash on Germination of 10 Species from Gorse Shrubland. Vegetatio 1 16: 123-131.

Hammer, Ø., Harper, A.T. \& Ryan, P.D. 2001. PAST: Palaeontological Statistics software package for education and data analysis. Palaeontologia Electronica 4: 9.

Hodgkinson, K.C. 1991. Shrub Recruitment Response to Intensity and Season of Fire in a Semiarid Woodland. Journal of Applied Ecology 28: 60-70.

Jones, M.B. \& Laude, H.M. 1960. Relationships between sprouting in chamise and the physiological condition of the plant. Journal of Range Management 13: 210-214.

Keeley, J.E. 2009. Fire intensity, fire severity and burn severity: a brief review and suggested usage. International Journal of Wildland Fire 18: 116-126.

Knapp, E., Estes, B. \& Skinner, C. 2009. Ecological effects of prescribed fire season: A literature review and synthesis for managers. General Technical Report PSW-GTR-223. USDA Forest Service, Pacific Southwest Research Station, Albany, CA, US.

Konstantinidis, P., Tsiourlis, G. \& Galatsidas, S. 2005. Effects of wildfire season on the resprouting of kermes oak (Quercus coccifera L.). Forest Ecology and Management 208: 15-27.

Konstantinidis, P., Tsiourlis, G. \& Xofis, P. 2006. Effect of fire season, aspect and pre-fire plant size on the growth of Arbutus unedo L. (strawberry tree) resprouts. Forest Ecology and Management 225: 359-367.
Lamont, B.B., Enright, N.J. \& He, T. 2011 . Fitness and evolution of resprouters in relation to fire. Plant Ecology 212: 19451957.

Loidi, J., Idoia, B., Campos, J.A., García-Mijangos, I. \& Herrera, M. 2010. A biogeographical analysis of the European Atlantic lowland heathlands. Journal of Vegetation Science 21: 832842.

Malanson, G.P. \& Trabaud, L. 1988. Vigour of post-fire resprouting by Quercus coccifera L. Journal of Ecology 76: 351-365.

Montiel, C. \& Kraus, D. (eds.). 2010. Best Practices of Fire Use Prescribed Burning and Suppression Fire Programmes in Selected Case-Study Regions in Europe. European Forest Institute Research Report 24. Joensuu, FI.

Moreira, B., Tormo, J., Estrelles, E. \& Pausas, J.G. 2010. Disentangling the role of heat and smoke as germination cues in Mediterranean Basin flora. Annals of Botany 105: 627-635.

Moreno, J.M., Cruz, A. \& Oechel, W.C. 1999. Allometric relationships in two lignotuberous species from Mediterraneantype climate areas of Spain and California. Journal of Mediterranean Ecology 1: 49-60.

Moreno, J.M., Zuazua, E., Pérez, B., Luna, B., Velasco, A. \& Resco de Dios, V. 2011 . Rainfall patterns after fire differentially affect the recruitment of three Mediterranean shrubs. Biogeosciences 8: 3721-3732.

Núñez, M.R., Bravo, F. \& Calvo, L. 2003. Predicting the probability of seed germination in Pinus sylvestris L. and four competitor shrub species after fire. Annals of Forest Science 60: $75-81$.

Ojeda, F., Marañón, T. \& Arroyo, J. 1996. Post-fire regeneration of a Mediterranean heathland in southern Spain. International Journal of Wildland Fire 6: 191-198.

Ojeda, F., Pausas, J.G. \& Verdú, M. 2010. Soil shapes community structure through fire. Oecologia 163: 1-7.

Ooi, M.K.J. 2010. Delayed emergence and post-fire recruitment success: effects of seasonal germination, fire season and dormancy type. Australian Journal of Botany 58: 248-256.

Papanastasis, V.P. 1980. Effects of season and frequency of burning on a phryganic rangeland in Greece. Journal of Range Management 33: 251-255.

Parker, V.T. 1987. Effects of wet-season management burns on chaparral vegetation: implications for rare species. In: Elias, T.S. (ed.). Proceedings of a California conference on the conservation and management of rare and endangered plants, pp. 231-237. California Native Plant Society, Sacramento, CA, US.

Pawlowsky-Glahn, V. \& Egozcue, J.J. 2006. Compositional data and their analysis: an introduction. In: Buccianti, A., MateuFigueras, G. \& Pawlowsky-Glahn, V. (eds.) Compositional Data Analysis in the Geosciences: From Theory to Practice, Volume 264. pp.145-159, Special Publication of the Geological Society, London, UK.

Pollet, P. \& Omi, N. 2002. Effect of thinning and prescribed burning on crown fire severity in ponderosa pine forests. International Journal of Wildland Fire 11: 1-10. 
Quintana, J.R., Cruz, A., Fernández-González, F. \& Moreno, J.M. 2004. Time of germination and establishment success after fire of three obligate seeders in a Mediterranean shrubland of Central Spain. Journal of Biogeography 31: 241249.

Reyes, O., Casal, M. \& Rego, F.C. 2009. Resprouting ability of six Atlantic shrub species. Folia Geobotanica 44: 19-29.

San-Miguel-Ayanz, J. \& Camia, A. 2009. Forest fires at a glance: facts, figures and trends in the EU. In: Birot, Y (ed.). Living with Wildfires: What Science Can Tell Us. A Contribution to the Science Policy Dialogue, Volume 15. pp. 11-18. European Forest Institute, Joensuu, FI.

Torres, I., Urbieta, I.R. \& Moreno, J.M. 2012. Vegetation and soil seed bank relationships across microhabitats in an abandoned Quercus suber parkland under simulated fire. Écoscience 19: 1-10.

Traba, J., Azcárate, F.M. \& Peco, B. 2006. The fate of seeds in Mediterranean soil seed banks in relation to their traits. Journal of Vegetation Science 17: 5-10.

Tutin, T.G., Heywood, V.H., Burges, N.A., Moore, D.M., Valentine, D.H., Walters, S.M. \& Webbs, D.A. 1964-1980. Flora Europaea. Cambridge University Press, Cambridge, UK.
Valbuena, L. \& Vera, M.L. 2002. The effects of thermal scarification and seed storage on germination of four heathland species. Plant Ecology 161: 137-144.

Vesk, P.A. \& Westoby, M. 2004. Sprouting ability across diverse disturbances and vegetation types worldwide. Journal of Ecology 92: 310-320.

\section{Supporting Information}

Additional supporting Information may be found in the online version of this article:

Appendix 1. Climate data near Gestosa and burning conditions.

Appendix 2. List of species.

Appendix 3. Allometric equations and biomass balance.

Appendix 4. Species richness and burning season.

Appendix 5. MANOVA test for changes in the relative dominance of the species. 